\title{
PENGARUH KEPERCAYAAN PELANGGAN TERHADAP NIAT PEMBELIAN GADGET DI SHOPEE INDONESIA
}

\author{
Maria Regina Picaully
}

Universitas Katolik Parahyangan

Email: maria.regina792@gmail.com

Submitted: Des 15, 2017; Reviewed: Des 18, 2018; Accepted: Apr 09, 2018

\begin{abstract}
Along with the development of e-commerce in Indonesia, customers are increasingly fond of shopping online to meet their needs including the needs of gadget products. However, despite the many benefits of online shopping, online shopping also has many risks to be faced. Meanwhile, whether or not a person's desire to shop online depends on the amount of benefits he receives when shopping compared to the risks he or she may encounter. One factor that can affect customers in shopping for gadgets online is the trust of customers towards online sellers. This is due to the difficulty of building trust between customers and sellers because they can not meet face to face and the product being sold can not be seen or held in the real way. This research uses descriptive and correlational method. Technique of collecting data of this research is spreading of questionaire to sample of research. After getting the data from the research sample then do the validity and reliability test data. Data that is valid and reliable then processed to know the respondent's assessment of customer trust and purchase intentions. To know the influence of customer trust on purchasing intention done linear regression analysis and test. After doing these tests then make conclusions and suggestions. From the results of research can be concluded that Shopee Indonesia's customers trust to gadget products are less good so affecting the intention of purchasing gadget products in Shopee Indonesia is not good
\end{abstract}

Keywords: word of mouth, customer trust, purchase intention

\section{PENDAHULUAN}

Teknologi telah berkembang sejak beberapa tahun yang lalu dan sekarang segalanya menjadi digital. Semua orang lebih memilih untuk melakukan aktivitasnya secara online sehingga internet menjadi sangat penting bagi mereka khususnya untuk pengguna internet di Indonesia. Melalui survei yang dilakukan oleh Asosiasi Penyelenggara Jaringan Internet Indonesia (APJII) dan Lembaga Polling Indonesia, lebih dari setengah masyarakat Indonesia telah terhubung ke internet. Pada tahun 2016, telah ada 132.7 juta dari 236.7 juta masyarakat Indonesia telah terhubung ke Internet (www.apjii.com).

Internet sudah menjadi bagian dari kehidupan masyarakat Indonesia karena memiliki berbagai manfaat seperti untuk kegiatan belajar, bekerja, berkomunikasi hingga berbelanja dapat dilakukan dengan mudah dan tanpa batasan.

Kemudahan dalam mengakses internet ini akhirnya mengubah gaya hidup masyarakat
Indonesia khususnya dalam hal berbelanja. Berbelanja secara online menjadi sangat diminati dibandingkan dengan berbelanja secara tradisional. Ada banyak alasan mengapa berbelanja secara online begitu diminati. Salah satu alasannya adalah pelanggan dapat membeli apapun kapanpun tanpa harus pergi ke toko. Setiap orang dapat mencari produk yang sama dengan membandingkan beberapa toko online yang berbeda. Berbelanja secara online juga dapat mengurangi tekanan bertemu muka dengan penjual dan banyak lagi.

Melalui fenomena ini, berbagai jenis toko online mulai menjamur untuk memudahkan pelanggan berbelanja. Berdasarkan hasil Sensus Ekonomi 2016 dari Badan Pusat Statistik (BPS) jumlah e-commerce di Indonesia selama 10 tahun meningkat sekitar $17 \%$ dan jumlah total usaha sekitar 26.2 juta. Sementara itu, nilai transaksi $e$ commerce di Indonesia pada tahun 2016 sendiri mencapai angka US\$ 4,89 miliar atau setara dengan Rp68 triliun meningkat dari jumlah total 
transaksi pada tahun 2015 yaitu sebesar US\$ 3,56 miliar (www.herosoftmedia.co.id).

Berbelanja online memang memberikan kemudahan dan keuntungan tersendiri, namun berbelanja online juga memiliki kelemahan seperti pelanggan tidak dapat memilih dan mengecek kondisi fisik barang. Selain itu, jual beli online tidak selalu aman. Tidak semua toko online benar-benar riil dan kredibel sehingga rawan dengan penipuan.

Selain itu, ada juga risiko dalam berbelanja online. Risiko pertama adalah ketidaksesuaian produk yang dipesan dengan gambar yang ditampilkan. Kedua adalah rusaknya barang yang diterima baik rusak dalam pengiriman dan cacat produksi. Risiko ketiga adalah kesalahan dalam pengepakan yang akan memunculkan kesalahan order baik berupa warna, jumlah maupun tipe. Risiko keempat adalah tidak terkirimnya barang karena hilang atau terlambat dan risiko kelima adalah munculnya penipuan (Turban, King, Lee \& Viehland dalam Widiyanto \& Prasilowati, 2015).

Kuat atau tidaknya keinginan seseorang untuk berbelanja secara online akan bergantung pada besar kecilnya manfaat yang diterima saat berbelanja secara online dibanding dengan risiko yang mungkin dialaminya ( $\mathrm{Yu} \& \mathrm{Wu}, 2007$ dalam Widiyanto \& Prasilowati, 2015).

Berdasarkan penelitian yang dilakukan oleh MARS Indonesia pada bulan Juni 2016 lalu, responden menyatakan alasan-alasan mengapa mereka tidak melakukan belanja online. Alasan pertama adalah lebih senang berbelanja offline sebesar $58.5 \%$, tidak mempercayai online shop sebesar $38.4 \%$, tidak dapat mencoba barang sebesar $32.7 \%$, transaksi yang memusingkan sebesar $14.6 \%$, takut terkena penipuan sebesar $3.8 \%$ dan takut barang tidak sesuai dengan pesanan sebesar $1.8 \%$.

Gadget adalah sebuah fitur berteknologi tinggi dan sebuah piranti atau instrumen yang memiliki tujuan dan fungsi praktis spesifik yang berguna dan umumnya diberikan terhadap sesuatu yang baru (Kuncoro, 2009 dalam Mariskhana, 2017). Salah satu bentuk instrumen gadget adalah handphone, tablet, notebook, laptop, dan kamera digital.

Sebelum membeli gadget ada pengecekan yang perlu dilakukan seperti pengecekan display, prosesor, kamera, baterai, user interface, storage, audio speaker, USB port dan headphone jack (gadgetsnow.com). Pengecekan ini tidak dapat dilakukan oleh pembeli apabila pembelian dilakukan secara online karena pembeli tidak dapat menyentuh dan mencoba barang tersebut.

Dalam pembelian gadget secara online, ada beberapa hal yang perlu diperhatikan seperti asal pemberian garansi, reputasi website, kecocokan nama dan nomor seri gadget, ulasan produk, garansi penggantian, rating penjual, ulasan dari pelanggan, metode pembayaran dan metode pengiriman (listamaze.com).

Di Indonesia sendiri terdapat banyak situs e-commerce untuk melakukan pembelian online seperti Lazada, Tokopedia, elevenia, Blibli.com, MatahariMall.com dan Shopee Indonesia. Berikut adalah 10 situs online retail produk kebutuhan konsumen yang paling banyak dikunjungi di Indonesia.

Shopee adalah satu dari 10 situs online di Indonesia yang memiliki banyak populasi digital hingga Juni 2017. Pertumbuhan Shopee sebesar $767 \%$ dalam semester pertama tahun 2017 menjadi kontribusi terbesar dalam pertumbuhan rata-rata pertumbuhan marketplace. Shopee juga memimpin untuk rata-rata durasi per view selama 16 menit (tekno.liputan6.com).

Namun, meskipun Shopee Indonesia mengalami pertumbuhan yang sangat pesat dalam semester pertama tahun 2017, untuk pembelian produk gadget sendiri lebih popular dilakukan di situs lain seperti Tokopedia.com, Bhinneka.com, Blanja.com, dan Lazada.com (Zopini.com).

Niat beli merupakan sesuatu yang berhubungan dengan rencana pelanggan untuk membeli produk tertentu serta berapa banyak unit produk yang dibutuhkan pada periode tertentu (Howard dalam Adriansyah \& Aryanto, 2011). Individu yang berniat terhadap suatu objek akan memiliki kekuatan atau dorongan untuk melakukan serangkaian tingkah laku untuk mendekati atau mendapatkan objek tersebut (Purba, 2012). Ada banyak kekuatan atau dorongan yang dapat menimbulkan niat beli dan salah satunya adalah kepercayaan pelanggan.

Berbelanja secara online memerlukan kepercayaan lebih karena tidak mudah untuk membangun kepercayaan diantara penjual dan pembeli online. Penjual dan pembeli tidak dapat bertemu secara langsung sehingga menyulitkan mereka untuk saling percaya. Penipuan dan kejahatan internet atau cybercrime juga mempengeruhi kepercayaan pelanggan. Terlebih lagi ketika barang yang dibeli oleh pelanggan adalah produk gadget.

Sementara itu, berdasarkan penelitian dari Wang, Chen dan Jiang (2009), kesuksesan e- 
commerce ditentukan dengan apakah pelanggan mempercayai penjual dan produk yang tidak dapat mereka lihat. Hasil studi empiris ini mengungkapkan bahwa kepercayaan dalam online shopping secara positif berpengaruh dengan aktivitas online shopping.

Oleh karena itu, kepercayaan pelanggan adalah faktor yang perlu diperhatikan dalam $e$ commerce dengan kata lain, penjual online perlu membangun kepercayaan pelanggannya agar mampu berhasil dalam e-commerce.

\section{RUMUSAN MASALAH PENELITIAN}

Berdasarkan latar belakang yang telah dikemukakan diatas, maka penulis merumuskan masalah sebagai berikut:

1. Bagaimana kepercayaan pelanggan pada produk gadget di Shopee Indonesia?

2. Bagaimana niat pembelian produk gadget di Shopee Indonesia?

3. Apakah kepercayaan pelanggan mempengaruhi niat pembelian produk gadget di Shopee Indonesia?

\section{TUJUAN PENELITIAN}

Berdasarkan perumusan masalah diatas, penelitian ini bertujuan untuk:

1. Mengetahui bagaimana kepercayaan pelanggan pada produk gadget di Shopee Indonesia.

2. Mengetahui bagaimana niat pembelian produk gadget di Shopee Indonesia.

3. Mengetahui pengaruh kepercayaan pelanggan terhadap niat pembelian produk gadget di Shopee Indonesia.

\section{HIPOTESIS PENELITIAN}

Berdasarkan latar belakang dan rumusan masalah yang telah dikemukakan, maka hipotesis penelitian ini adalah:

1. Kepercayaan pelanggan mempengaruhi niat pembelian gadget di Shopee Indonesia.

\section{TINJAUAN PUSTAKA \\ E-Commerce}

E-commerce didefinisikan sebagai proses pembelian, penjualan, mentransfer atau bertukar produk, jasa atau informasi melalui jaringan komputer melalui Internet (Kozinets et al., 2010 dalam Irmawati, 2011).

Menurut Sandhausen, bentuk-bentuk $e$ commerce ada enam (Sandhausen, 2008 dalam Pradana, 2015), yaitu:

1. B2B (Business to Business)
Transaksi bisnis antara pelaku bisnis dengan pelaku bisnis lainnya. Dapat berupa kesepakatan spesifik yang mendukung kelancaran bisnis.

2. B2C (Business to Consumer)

Aktivitas yang dilakukan produsen kepada konsumen secara langsung.

3. $\mathrm{C} 2 \mathrm{C}$ (Consumer to Consumer)

Aktivitas bisnis (penjualan) yang dilakukan oleh individu kepada individu lainnya.

4. C2B (Consumer to Business)

C2B merupakan model bisnis dimana individu menciptakan dan membentuk nilai akan proses bisnis.

5. $\mathrm{B} 2 \mathrm{G}$ (Business to Government)

Merupakan turunan dari B2B, perbedaannya adalah proses ini terjadi antara pelaku bisnis dan instansi pemerintah.

6. G2C (Government to Consumer)

Merupakan hubungan atau interaksi antara pemerintah dengan masyarakat. Konsumen, dalam hal ini masyarakat, dapat dengan mudah menjangkau pemerintah sehingga memperoleh kemudahan dalam pelayanan sehari-hari.

\section{Kepercayaan Pelanggan (Customer Trust)}

Kepercayaan pelanggan adalah semua pengetahuan yang dimiliki oleh pelanggan dan semua kesimpulan yang dibuat pelanggan tentang objek, atribut dan manfaatnya. Kepercayaan pelanggan adalah pengetahuan pelanggan tentang suatu produk atau jasa yang diyakini memiliki kualitas dan manfaat (Mowen dan Minor, 2002 dalam Bahrudin \& Zuhro, 2015).

Dalam konteks e-commerce, kepercayaan pelanggan dapat dilihat dari adanya kemauan untuk terlibat dalam kegiatan dan berhubungan via online. Peningkatan kepercayaan di dalam toko online mengurangi persepsi pelanggan tentang risiko dan mempengaruhi tingkah laku pelanggan terhadap toko online dan akan meningkatkan keinginan untuk membeli dari toko tersebut (Fajarratri, 2010).

Kepercayaan merupakan suatu pondasi dalam sebuah proses bisnis. Suatu transaksi antara dua pihak atau lebih akan terjadi apabila kedua belak pihak saling mempercayai (Anwar \& Adidarma, 2016).

Dimensi dari customer online trust termasuk security, privacy dan reliability. (Ling, Chai, \& Piew, 2010)

1. Security didefinisikan sejauh mana pelanggan percaya bahwa Internet aman 
untuk mengirimkan informasi sensitif mereka pada transaksi bisnis. Keamanan memiliki peran penting dalam mempengaruhi perilaku konsumen dan niat pembelian karena adanya perceived risk dalam mengirimkan informasi sensitif seperti nomor kartu kredit di Internet. Konsumen mungkin merasa kurang nyaman untuk memberikan informasi personal melalui Internet karena konsumen tidak dapat secara fisik mengecek kualitas produk atau memonitor keamanan ketika berbelanja di Internet.

2. Privacy adalah kepercayaan konsumen mengenai kinerja pihak lain dalam lingkungan ketika melakukan transaksi atau perilaku konsumsi.

3. Company reliability adalah asumsi konsumen bahwa perusahaan besar memiliki kemampuan untuk meningkatkan kepercayaan mereka dan perusahaan yang memiliki reputasi yang baik meningkatkan kepercayaan konsumen.

Lebih lanjut, dalam studi McKnight dan Chervany komponen kepercayaan adalah integritas, benevolence, competency dan predictability (McKnight dan Chervany, 2002 dalam Anwar \& Adidarma, 2016). Komponenkomponen kepercayaan adalah sebagai berikut:

1. Integritas adalah kejujuran dan kemampuan menepati janji dari pihak yang dipercaya (penjual). Integritas berkaitan dengan bagaimana perilaku atau kebiasaan penjual dalam menjalankan bisnisnya. Integritas dapat dilihat dari sudut keterbukaan (openness), pemenuhan (fulfillment), kesetiaan (loyalty), kejujuran (honesty), keterkaitan (dependability) dan kehandalan (reliability).

2. Benevolence atau kebaikan hati adalah perhatian dan motivasi untuk bertindak sesuai dengan kepentingan pelanggan oleh penyedia barang. Kebaikan hati merupakan kemauan penjual dalam memberikan kepuasan yang saling menguntungkan antara dirinya dengan pelanggan. Penjual bukan semata-mata mengejar keuntungan maksimum semata, melainkan juga memiliki perhatian yang besar dalam mewujudkan kepuasan konsumen. Komponen ini meliputi perhatian, empati, keyakinan dan daya terima.

3. Competency adalah kemampuan penjual untuk melaksanakan kebutuhan dari pelanggan. Dalam hal ini, bagaimana penjual mampu menyediakan, melayani sampai mengamankan transaksi dari gangguan pihak lain. Artinya bahwa pelanggan memperoleh jaminan kepuasan dan keamanan dari penjual dalam melakukan transaksi. Komponen ini meliputi pengalaman, pengesahan institusional dan kemampuan dalam ilmu pengetahuan.

4. Predictability adalah konsistensi perilaku oleh penjual. Kemampuan penjual untuk memberikan kepastian akan barang yang dijual, sehingga pelanggan dapat mengantisipasi dan memprediksi tentang kinerja penjual. Komponen ini meliputi citra diri penjual, risiko atau akibat yang mampu diprediksi dan konsistensi.

\section{Niat Beli (Purchase Intention)}

Menurut Kotler (2005) niat beli merupakan suatu hal yang mendahului dan menentukan setiap pelanggan. Niat adalah kecenderungan untuk melakukan tindakan atau perilaku atau sesuatu yang segera mendahului tingkah laku pembelian yang sebenarnya.

Sementara itu, niat merupakan salah satu aspek psikologis yang memiliki pengaruh cukup besar terhadap sikap perilaku. Niat beli dapat diartikan sebagai suatu sikap senang terhadap suatu objek yang membuat individu berusaha untuk mendapatkan objek tersebut dengan cara membayarnya dengan uang atau pengorbanan (Schiffman dan Kanuk, 2007 dalam Maghfiroh, Arifin, \& Sunarti, 2016)

Indikator-indikator niat beli dijelaskan beberapa komponen seperti ketertarikan untuk mencari informasi tentang produk, mempertimbangkan untuk membeli, tertarik untuk mencoba, ingin mengetahui produk dan keinginan memiliki produk (Schiffman \& Kanuk, 2008 dalam Randi, 2016). Komponen-komponen tersebut adalah sebagai berikut:

1. Tertarik untuk mencari informasi tentang produk

Pelanggan yang terangsang kebutuhannya akan terdorong untuk mencari informasi yang lebih banyak. Pertama, pencarian informasi yang lebih ringan (penguatan perhatian). Pada level ini, orang hanya sekedar lebih peka terhadap informasi produk. Kedua, level aktif mencari informasi termasuk di dalamnya mencari bahan bacaan, bertanya pada teman atau mengunjungi toko untuk mempelajari produk tertentu.

2. Mempertimbangkan untuk membeli 
Melalui pengumpulan informasi, pelanggan mempelajari merek-merek yang bersaing serta fitur merek tersebut. Melakukan evaluasi terhadap pilihan-pilihan dan mulai mempertimbangkan untuk membeli produk.

3. Tertarik untuk mencoba

Setelah pelanggan berusaha memenuhi kebutuhan, mempelajari merek-merek yang bersaing serta fitur merek tersebut, pelanggan akan mencari manfaat tertentu dari solusi produk dan melakukan evaluasi terhadap produk-produk tersebut. Evaluasi ini dianggap sebagai proses yang berorientasi kognitif. Maksudnya adalah pelanggan dianggap menilai suatu produk secara sangat sadar dan rasional sehingga mengakibatkan ketertarikan untuk mencoba.

4. Ingin mengetahui produk

Setelah memiliki ketertarikan untuk mencoba suatu produk, pelanggan akan memiliki keinginan untuk mengetahui produk. Pelanggan akan memandang produk sebagai sekumpulan atribut dengan kemampuan yang berbeda-beda dalam memberikan manfaat yang digunakan untuk memuaskan kebutuhan.

5. Keinginan memiliki produk

Para pelanggan akan memberikan perhatian besar pada atribut yang memberikan manfaat yang dicarinya. Akhirnya pelanggan akan mengambil sikap (keputusan preferensi) terhadap produk melalui evaluasi atribut dan membentuk niat untuk membeli atau memiliki produk yang disukai.

Indikator dari niat beli melalui online shopping adalah keinginan untuk segera membeli produk yang dijual oleh toko online. Jika seseorang berniat atau menginginkan produk atau jasa yang ditawarkan oleh toko online dan merasa tertarik untuk memilikinya, maka mereka berusaha untuk membeli produk atau jasa tersebut dengan melakukan online shopping. Intensitas pencarian informasi membuat orang selalu mencari informasi mengenai produk atau jasa, hal ini dapat menandakan bahwa seseorang memiliki niat beli yang tinggi. Selain itu, terdapat pula niat yang menggambarkan preferensi produk atau jasa yang hanya dapat diganti bila terjadi sesuatu dengan produk atau jasa preferensinya. Dengan kata lain, seseorang akan memiliki preferensi utama produk yang dijual pada salah satu toko online dan akan mengabaikan pilihan produk toko online yang lain. (Fajarratri, 2010)

\section{METODE PENELITIAN \\ Jenis Penelitian}

Penelitian ini bertujuan untuk memaparkan karakteristik variabel-variabel yang menarik dari situasi yang diteliti dan memberikan gambaran secara sistematis fakta atau karakteristik populasi tertentu atau bidang tertentu secara aktual dan cermat sehingga penelitian ini termasuk penelitian deskriptif (Sekaran \& Bougie, 2010).

Penelitian ini juga menggunakan metode korelasional dimana metode ini menjelaskan hubungan antara variabel yang diteliti. Tujuannya adalah meneliti seberapa jauh variabel pada satu faktor yang berkaitan dengan variasi pada faktor lainnya.

\section{Teknik Pengumpulan Data}

Teknik pengumpulan data yang digunakan adalah dengan mengumpulkan data primer melalui pembagian kuesioner online kepada sampel penelitian.

\section{Populasi dan Sampel Penelitian}

Populasi tidak terbatas dan karena keterbatasan waktu, biaya dan lain-lain maka penulis menggunakan sampel (Sekaran \& Bougie, 2010).

Sementara itu, penelitian ini menggunakan nonprobability sampling dimana elemen dalam populasi tidak memiliki probabilitas untuk dipilih sebagai subjek sampel. Teknik sampling yang digunakan adalah teknik purposive sampling dimana penentuan sampel dengan pertimbangan khusus sehingga layak dijadikan sampel. Adapun jumlah sampel tersebut diperoleh dari perhitungan adalah 97 (Aaker, Kumar dan Day 2001). Rumus perhitungan tersebut adalah sebagai berikut:

$$
\begin{aligned}
& n=\frac{0.25 \times z^{2}}{e^{2}} \\
& n=\frac{0.25 \times\left(1.96^{2}\right)}{\left(0.1^{2}\right)}=96.04 \approx 97
\end{aligned}
$$

\section{Keterangan:}

$\mathrm{n}=$ ukuran sampel minimum

$\mathrm{Z}=$ nilai $\mathrm{z}$ untuk interval kepercayaan $\alpha$

$\mathrm{e}=$ tingkat kesalahan

Sampel penelitian yang akan diambil adalah sebanyak 120 orang yang melakukan pembelian di Shopee Indonesia selama 1 tahun terakhir dan belum pernah membeli produk gadget di Shopee Indonesia sebelumnya. 


\section{Operasionalisasi Variabel}

Berikut adalah operasionalisasi variabel penelitian ini:

Tabel 1. Operasionalisasi Variabel

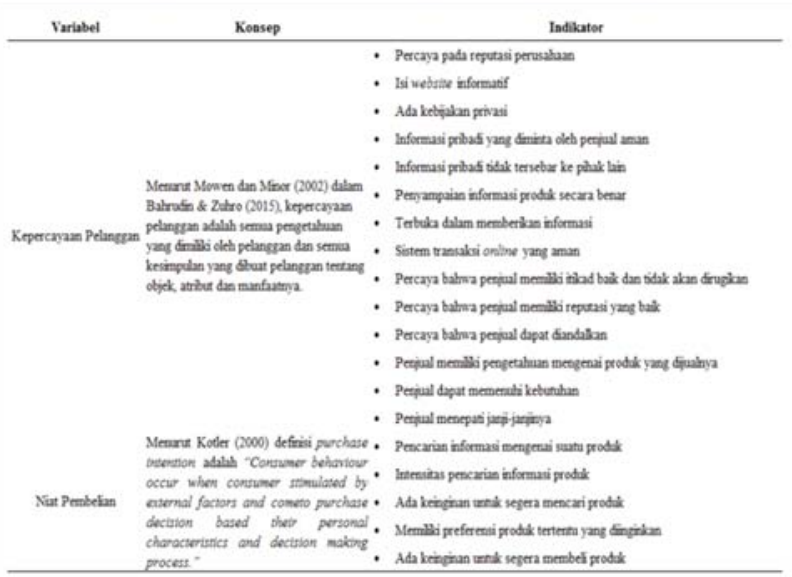

Teknik Analisis Data

Teknik analisis data yang digunakan dalam penelitian ini adalah menggunakan analisis regresi linier sederhana. Regresi linier sederhana adalah hubungan secara linier antara satu variabel independen (X) dengan variabel dependen $(\mathrm{Y})$. Analisis ini untuk mengetahui arah hubungan antara variabel independen dengan variabel dependen.

Selanjutnya, untuk mengetahui pengaruh antara variabel independen terhadap variabel dependen, maka digunakan uji t. Uji t digunakan untuk mengetahui pengaruh signifikansi variabel independen terhadap variabel dependennya (Ghozali, 2011).

Hipotesis yang akan diuji adalah sebagai berikut:

- Jika t hitung $>\mathrm{t}$ tabel, maka $\mathrm{H}_{0}$ ditolak

- Jika thitung $\leq \mathrm{t}$ tabel, maka $\mathrm{H}_{0}$ diterima

\section{PEMBAHASAN}

\section{Penilaian Responden terhadap Kepercayaan Pelanggan terhadap Produk Gadget di Shopee Indonesia}

Setelah mengumpulkan jawaban dari responden, selanjutnya jawaban tersebut diolah dengan melakukan pembobotan. Hasil dari pembobotan tersebut kemudian diinterpretasikan menjadi 5 kategori seperti pada tabel berikut.
Tabel 2. Interpretasi Kategori Jawaban Responden

\begin{tabular}{ll} 
Kategori Persentase & \multicolumn{1}{c}{ Interpretasi } \\
\hline $4,20<x \leq 5$ & Sangat Setuju \\
$3,40<x \leq 4,20$ & Setuju \\
$2,60<x \leq 3,40$ & Kurang Setuju \\
$1,80<x \leq 2,60$ & Tidak Setuju \\
$1<x \leq 1,80$ & Sangat Tidak Setuju \\
\hline
\end{tabular}

Sumber: Simamora (2002)

Ada 12 indikator yang digunakan untuk menilai kepercayaan pelanggan pada produk gadget di Shopee Indonesia. Berikut adalah hasil penilaian responden mengenai kepercayaan pelanggan pada produk gadget di Shopee Indonesia.

Tabel 3. Penilaian Responden terhadap Kepercayaan Pelanggan pada Produk Gadget Shopee Indonesia

\begin{tabular}{|c|c|c|c|}
\hline No & Pernyataan & Bobot Rata-Rata & Interpretasi \\
\hline 1 & $\begin{array}{l}\text { Saya percaya Shopee Indonesia memiliki } \\
\text { reputasi yang baik }\end{array}$ & 3.77 & Setuju \\
\hline 2 & $\begin{array}{l}\text { Saya percaya pada keamanan informasi } \\
\text { pribadi yang diminta oleh Shopee Indonesia } \\
\text { seperti orang lain tidak dapat mengakses } \\
\text { informasi pribadi saya }\end{array}$ & 3.66 & Setuju \\
\hline & Saya percaya informasi pribadi yang & & \\
\hline 3 & $\begin{array}{l}\text { diminta Shopee Indonesia tidak akan } \\
\text { tersebar ke pihak lain }\end{array}$ & 3.7 & Setuju \\
\hline 4 & $\begin{array}{l}\text { Saya percaya transaksi yang dilahukan } \\
\text { aman } \\
\text { Saya percaya penjual gadget di Shopee }\end{array}$ & 4.28 & Setuju \\
\hline 5 & $\begin{array}{l}\text { Indonesia menyampaikan informasi secara } \\
\text { benar dan jujur } \\
\text { Saya percaya penjual gadget di Shopee }\end{array}$ & 3.16 & Kurang Setuju \\
\hline 6 & $\begin{array}{l}\text { Indonesia menyampaikan informasi secara } \\
\text { terbuka } \\
\text { Saya percaya bahwa penjual gadget di }\end{array}$ & 2.87 & Kurang Setuju \\
\hline 7 & $\begin{array}{l}\text { Shopee Indonesia memiliki itikad baik dan } \\
\text { tidak akan merugkan saya } \\
\text { Saya percaya bahwa penjual gadget di }\end{array}$ & 3.11 & Kurang Setuju \\
\hline 8 & $\begin{array}{l}\text { Shopee Indonesia memiliki reputasi yang } \\
\text { baik }\end{array}$ & 2.95 & Kurang Setuju \\
\hline 9 & $\begin{array}{l}\text { Saya percaya bahwa penjual gadget di } \\
\text { Shopee Indonesia dapat diandalkan }\end{array}$ & 2.93 & Kurang Setuju \\
\hline 10 & $\begin{array}{l}\text { Saya percaya penjual gadget di Shopee } \\
\text { Indonesia memilili pengetahuan yang baik } \\
\text { mengenai produk gadget yang djualnya }\end{array}$ & 3.33 & Kurang Setuju \\
\hline 11 & $\begin{array}{l}\text { Saya percaya penjual gadget di Shopee } \\
\text { Indonesia dapat memenuhi kebutuhan saya }\end{array}$ & 2.74 & Kurang Setuju \\
\hline 12 & $\begin{array}{l}\text { Saya percaya bahwa penjual gadget di } \\
\text { Shopee Indonesia akan menepati janji- } \\
\text { janjinya }\end{array}$ & 3.03 & Kurang Setuju \\
\hline & Total Rata-Rata & 3.29 & Kurang Setuju \\
\hline
\end{tabular}

Sumber: Hasil Pengolahan Data

Berdasarkan hasil pada tabel di atas, maka dapat diketahui bahwa responden menilai kurang percaya untuk membeli produk gadget di Shopee Indonesia. Responden menilai percaya bahwa Shopee Indonesia memiliki reputasi yang baik, 
percaya pada keamanan informasi pribadi yang diminta oleh Shopee Indonesia seperti orang lain tidak dapat mengakses informasi pribadi responden, percaya informasi pribadi yang diminta Shopee Indonesia tidak akan tersebar ke pihak lain dan percaya transaksi yang dilakukan aman.

Namun, reponden menilai kurang percaya pada penjual gadget di Shopee Indonesia menyampaikan informasi secara benar dan jujur, kurang percaya penjual gadget di Shopee Indonesia menyampaikan informasi secara terbuka, kurang percaya penjual gadget di Shopee Indonesia memiliki itikad baik dan tidak akan merugikan responden, kurang percaya penjual gadget di Shopee Indonesia memiliki reputasi yang baik, kurang percaya penjual gadget di Shopee Indonesia dapat diandalkan, kurang percaya penjual gadget di Shopee Indonesia memiliki pengetahuan yang baik mengenai produk gadget yang dijualnya, dan kurang percaya penjual gadget di Shopee Indonesia dapat memenuhi kebutuhan dan penjual gadget di Shopee Indonesia akan menepati janji-janjinya.

\section{Penilaian Responden terhadap Niat Pembelian Produk Gadget di Shopee Indonesia}

Ada 5 indikator yang digunakan untuk menilai niat pembelian produk gadget di Shopee Indonesia. Berikut adalah hasil penilaian responden mengenai niat pembelian produk gadget di Shopee Indonesia.

Tabel 4. Penilaian Responden terhadap Niat Pembelian Produk Gadget di Shopee Indonesia

\begin{tabular}{|c|c|c|c|}
\hline No & Pernyataan & Bobot Rata-Rata & Interpretasi \\
\hline 1 & $\begin{array}{l}\text { Saya tertank untuk mencari informasi mengenai produk gadget } \\
\text { seperti kualitas produk, variasi produk dan harga produlk di } \\
\text { Shopee Indonesia }\end{array}$ & 2.95 & Kurang Setuju \\
\hline 2 & $\begin{array}{l}\text { Saya sering mencari informasi mengenai produk gadiget di } \\
\text { Shopee Indonesia }\end{array}$ & 2.32 & Tidak Setuju \\
\hline 3 & Saya ingin mencari produk gadget melalui Shopee Indonesia & 2.67 & Kurang Setuju \\
\hline 4 & $\begin{array}{l}\text { Saya mempunyai kecenderungan pada pilhan produk gadget } \\
\text { tertentu (preferensi) di Shopee Indonesia }\end{array}$ & 2.25 & Tidak Setuju \\
\hline 5 & Saya ingin membeli produk gadget di Shopee Indonesia & 2.58 & Tidak Setuju \\
\hline & Total Rata-Rata & 2.55 & Tidak Setuju \\
\hline
\end{tabular}

Sumber: Hasil Pengolahan Data

Berdasarkan hasil pada tabel di atas, maka dapat diketahui responden tidak berniat untuk melakukan pembelian produk gadget di Shopee Indonesia. Responden kurang tertarik untuk mencari informasi mengenai produk gadget di Shopee Indonesia. Responden juga tidak mencari informasi mengenai produk gadget di Shopee
Indonesia dan kurang ingin mencari produk gadget di Shopee Indonesia. Sementara itu, responden tidak mempunyai preferensi produk gadget di Shopee Indonesia dan tidak ingin membeli produk gadget di Shopee Indonesia.

Pengaruh Kepercayaan Pelanggan terhadap Niat Pembelian Produk Gadget di Shopee Indonesia

Analisis Regresi Linier

Persamaan regresi linier pada penelitian ini adalah sebagai berikut:

$$
Y=a+b X+e
$$

Keterangan:

$\mathrm{Y}=$ niat pembelian

$\mathrm{a}=$ konstanta

$\mathrm{b}=$ slope/besar pengaruh $\mathrm{X}$ terhadap $\mathrm{Y}$

$\mathrm{e}=$ error

Tabel 5. Hasil SPSS Persamaan Regresi Linier

\begin{tabular}{|c|c|c|c|c|c|c|}
\hline \multirow{4}{*}{ Model } & & \multirow{3}{*}{\multicolumn{2}{|c|}{$\begin{array}{l}\text { Coefficients' } \\
\text { Unstandardized } \\
\text { Coefficients }\end{array}$}} & \multirow{4}{*}{$\begin{array}{l}\text { Standardized } \\
\text { Coeefficients } \\
\text { Beta }\end{array}$} & \multirow{4}{*}{$t$} & \multirow{4}{*}{ Sig. } \\
\hline & & & & & & \\
\hline & & & & & & \\
\hline & & B & Std. Error & & & \\
\hline \multirow{2}{*}{1} & (Constant) & -0.146 & 0.182 & & -0.802 & 0.424 \\
\hline & KepercayaanPelanggan & 0.791 & 0.114 & 0.537 & 6.91 & 0 \\
\hline
\end{tabular}

Berdasarkan hasil pada tabel di atas, diperoleh bentuk persamaan regresi linier penelitian sebagai berikut:

$$
Y=-0.146+0.791 X+e
$$

1. Konstanta sebesar -0.146 artinya jika kepercayaan pelanggan (X) nilainya adalah 0 maka niat pembelian produk gadget di Shopee Indonesia (Y) nilainya negatif yaitu sebesar -0.146

2. Koefisien regresi untuk variabel kepercayaan pelanggan (X) sebesar 0.791, artinya jika kepercayaan mengalami kenaikan sebesar 1, maka niat pembelian (Y) akan mengalami peningkatan sebesar 0.791 . Koefisien bernilai positif artinya terjadi hubungan positif antara kepercayaan pelanggan dengan niat pembelian. menunjukkan adanya hubungan yang searah antara kepercayaan pelanggan $(\mathrm{X})$ dengan niat pembelian $(\mathrm{Y})$.

\section{Koefisien Determinasi}

Koefisien determinasi digunakan untuk melihat seberapa besar kontribusi variabel independen penelitian berpengaruh terhadap variabel 
dependen. Koefisien determinasi dapat dilihat pada tabel berikut:

Tabel 6. Koefisien Determinasi

\begin{tabular}{|c|c|c|c|c|c|}
\hline \multicolumn{6}{|c|}{ Model Summary } \\
\hline Model & & $\mathbf{R}$ & R Square & $\begin{array}{l}\text { Adjusted R } \\
\text { Square }\end{array}$ & $\begin{array}{l}\text { Std. Error of the } \\
\text { Estimate }\end{array}$ \\
\hline & 1 & $.537^{2}$ & 0.288 & 0.282 & 0.07482 \\
\hline
\end{tabular}

a. Predictors: (Constant), KepercayaanPelanggan

Berdasarkan hasil pada tabel di atas, variabel kepercayaan pelanggan memberikan pengaruh sebesar $28.8 \%$ terhadap niat pembelian produk gadget di Shopee Indonesia sementara sebesar $71.2 \%$ merupakan kontribusi variabel lain yang tidak diteliti dalam penelitian ini.

\section{Analisa Pengaruh Kepercayaan Pelanggan terhadap Niat Pembelian Produk Gadget di Shopee Indonesia}

Analisis pengaruh digunakan untuk mengetahui keberadaan pengaruh variabel independen terhadap variabel dependen. Hipotesis yang akan diuji adalah sebagai berikut:

- Jika t hitung $>\mathrm{t}$ tabel, maka $\mathrm{H}_{0}$ ditolak

- Jika t hitung $\leq \mathrm{t}$ tabel, maka $\mathrm{H}_{0}$ diterima

Analisis pengaruh parsial berdasarkan hasil pengolahan software SPSS adalah sebagai berikut:

Tabel 7. Hasil SPPS Uji t

\begin{tabular}{|c|c|c|c|c|c|c|}
\hline \multicolumn{7}{|c|}{ Coefficients ${ }^{2}$} \\
\hline \multirow{2}{*}{ Model } & & \multicolumn{2}{|c|}{$\begin{array}{c}\text { Unstandardized } \\
\text { Coefficients }\end{array}$} & \multirow{2}{*}{$\begin{array}{l}\text { Standardized } \\
\text { Coefficients } \\
\text { Beta }\end{array}$} & \multirow{2}{*}{$t$} & \multirow{2}{*}{ Sig. } \\
\hline & & $B$ & Std. Error & & & \\
\hline \multirow{2}{*}{1} & (Constant) & -0.146 & 0.182 & & -0.802 & 0.424 \\
\hline & KepercayaanPelanggan & 0.791 & 0.114 & 0.537 & 6.91 & 0 \\
\hline
\end{tabular}

Berdasarkan hasil analisis SPSS di atas, maka didapatkan hasil dari pengujian hipotesis yaitu:

Uji hipotesis kepercayaan pelanggan (X) terhadap niat pembelian $(\mathrm{Y})$ :

Hasil $t$ hitung berdasarkan tabel SPSS untuk variabel kepercayaan pelanggan $(\mathrm{X})$ yaitu sebesar 6.910 sedangkan $\mathrm{t}$ tabel untuk $\mathrm{df}=117$ adalah 1.657. Hal ini menunjukkan bahwa $t$ hitung $>\mathrm{t}$ tabel $(6.910>1.657)$, maka dari itu $\mathrm{H}_{0}$ ditolak dan ini berarti bahwa terdapat pengaruh antara variabel kepercayaan pelanggan $(\mathrm{X})$ terhadap niat pembelian (Y).

Kepercayaan pelanggan mempengaruhi niat pembelian produk gadget di Shopee Indonesia. Kepercayaan di antara pembeli dan penjual sangat diperlukan dalam transaksi online. 38
Pelanggan merasa kurang percaya pada penjual produk gadget di Shopee Indonesia sehingga pelanggan tidak berniat untuk melakukan pembelian produk gadget di Shopee Indonesia.

Kurangnya informasi yang diberikan oleh penjual secara jujur dan terbuka serta reputasi yang kurang baik akan menyebabkan kurangnya kepercayaan pelanggan terhadap penjual produk gadget di Shopee Indonesia. Oleh karena kurangnya kepercayaan pelanggan maka pelanggan tidak berniat melakukan pembelian produk gadget di Shopee Indonesia.

\section{KESIMPULAN DAN SARAN Kesimpulan}

Setelah melakukan penelitian dengan mengumpulkan data serta mengolahnya, maka dapat ditarik kesimpulan untuk menjawab rumusan masalah yang telah disusun. Berdasarkan hasil analisis penulis dalam penelitian ini maka dapat disimpulkan:

1. Kepercayaan pelanggan Shopee Indonesia kurang baik. Pelanggan Shopee Indonesia merasa percaya pada Shopee Indonesia, seperti percaya pada reputasi Shopee Indonesia, percaya pada keamanan informasi pribadi dan juga percaya pada keamanan transaksi yang dilakukan. Namun, pelanggan Shopee Indonesia kurang mempercayai penjual gadget di Shopee Indonesia seperti penyampaian informasi secara benar dan jujur oleh penjual gadget di Shopee Indonesia, pernyampaian informasi secara terbuka, itikad baik penjual dan reputasi penjual, keandalan penjual, pengetahuan penjual mengenai produk, kepercayaan penjual akan dapat memenuhi kebutuhan pelanggan dan kurang percaya penjual akan menepati janji-janjinya

2. Pelanggan Shopee Indonesia tidak berniat untuk melakukan pembelian gadget di Shopee Indonesia. Hal ini dapat dilihat melalui kurang tertariknya pelanggan untuk mencari informasi mengenai produk gadget di Shopee Indonesia. Pelanggan juga tidak sering mencari informasi mengenai produk gadget di Shopee Indonesia dan kurang ingin mencari produk gadget di Shopee Indonesia. Pelanggan juga tidak memiliki preferensi produk gadget di Shopee Indonesia dan pelanggan tidak ingin membeli produk gadget di Shopee Indonesia.

3. Kepercayaan pelanggan mempengaruhi niat pembelian produk gadget di Shopee 
Indonesia. Kepercayaan pelanggan terhadap produk gadget di Shopee Indonesia berpengaruh terhadap niat pembelian. Jika kepercayaan pelanggan terhadap produk gadget di Shopee Indonesia meningkat, maka niat pembelian produk gadget di Shopee Indonesia juga akan meningkat. Sebaliknya, jika kepercayaan pelanggan terhadap produk gadget di Shopee Indonesia menurun, maka niat pembelian produk gadget di Shopee Indonesia akan menurun. Oleh karena itu, kepercayaan pelanggan perlu dibangun oleh penjual gadget di e-commerce khususnya Shopee Indonesia untuk membangun kepercayaan pelanggannya agar dapat meningkatkan niat pembelian produk gadget di Shopee Indonesia.

4. Topik mengenai e-commerce adalah topik yang menarik untuk diangkat karena perkembangan e-commerce yang pesat. Oleh karena itu, penting bagi pelaku di e-commerce untuk memahami hal-hal yang dapat mempengaruhi kesuksesan dalam ecommerce. Penelitian ini mengungkapkan bahwa kepercayaan pelanggan adalah hal yang penting untuk diperhatikan karena dapat kepercayaan dapat mempengaruhi niat pembelian khususnya produk gadget di Shopee Indonesia.

\section{Saran}

Setelah melakukan penelitian dan menarik kesimpulan, penulis mencoba memberikan saran yang dapat digunakan untuk membantu pihakpihak yang terkait dalam mengatasi permasalahan yang ada.

1. Para penjual gadget di Shopee Indonesia dapat memberikan informasi yang lebih mendetail mengenai produk yang dijualnya sehingga pelanggan akan merasa penjual lebih jujur dan terbuka. Selain itu, penjual gadget di Shopee Indonesia juga dapat meningkatkan reputasinya dengan menjawab keluhan dan pertanyaan pelanggan yang ada di tokonya sehingga pelanggan merasa penjual memiliki itikad baik dan tidak akan merugikan pelanggan.

2. Shopee Indonesia juga bisa lebih memperkenalkan fitur garansi dengan memberikan informasi atau sosialisasi lebih agar pelanggan dapat mengetahui dan menggunakan fitur tersebut. Fitur garansi juga diharapkan dapat meningkatkan kepercayaan pelanggan dalam berbelanja khususnya produk gadget di Shopee Indonesia karena pelanggan mendapat jaminan bahwa barang yang dibelinya asli dan aman hingga di tangan pelanggan.

3. Untuk penelitian selanjutnya, masih ada banyak variabel yang dapat mempengaruhi niat pembelian khususnya produk gadget di Shopee Indonesia selain kepercayaan pelanggan sehingga masih ada banyak variabel yang dapat diteliti di masa depan.

\section{REFERENSI}

Aaker, D., Kumar, V., \& Day, G. (2001). Marketing Research. Wiley.

Adriansyah, M. A., \& Aryanto, R. (2011). Pengaruh Kualitas Produk terhadap Minat Pembelian Serta Dampaknya Terhadap Proses Keputusan Pembelian J\&C Cookies.

Anwar, R., \& Adidarma, W. (2016). Pengaruh Kepercayaan dan Risiko pada Minat Beli Belanja Online. Jurnal Manajemen dan Bisnis Sriwijaya, 155-168.

Asosiasi Penyedia Jasa Internet Indonesia. (2017, Agustus 15). Retrieved from www.apjii.com: www.apjii.com

Bahrudin, M., \& Zuhro, S. (2015). Pengaruh Kepercayaan dan Kepuasan Pelanggan terhadap Loyalitas Pelanggan. Jurnal Bisnis dan Manajemen Islam.

Fajarratri, D. A. (2010). Studi Mengenai Persepsi Risiko (Perceived Risk) terhadap Minat Beli Online Shopping (Kasus pada Toko Online www.Kaskus.com). Jurnal Sains Pemasaran Indonesi, 111-127.

Ghozali, I. (2011). Aplikasi Analisis Multivariate dengan Program SPSS. Semarang: Badan Penerbit Universitas Diponegoro.

Irmawati, D. (2011). Pemanfaatan E-Commerce dalam Dunia Bisnis. Junal Ilmiah Orasi Bisnis, 95-112.

Kotler, P. (2005). Manajemen Pemasaran. Jakarta: Indeks.

Ling, K. C., Chai, L. T., \& Piew, T. H. (2010). The Effects of Shopping Orientations, Online Trust and Prior Online Purchase Experience toward Customers' Online Purchase Intention. International Business Research, 63-76.

Maghfiroh, A., Arifin, Z., \& Sunarti. (2016). Pengaruh Citra Merek terhadap Minat Beli dan Keputusan Pembelian. Jurnal Administrasi Bisnis, 132-140. 
Mariskhana, K. (2017). Pengaruh Televisi dan Gadget terhadap Prestasi Belajar Anak. Tangerang.

Pradana, M. (2015). Klasifikasi Bisnis ECommerce di Indonesia. MODUS Journals, 163-174.

Purba, J. S. (2012). Analisis Pengaruh Persepsi Nilai Konsumen terhadap Minat Beli Produk Private Label Hypermart Carrefour di Kota Semarang. Semarang: Universitas Diponegoro.

Randi. (2016). Pengaruh Citra Merek terhadap Minat Beli Makanan Fast Food Ayam Goreng (Studi pada Konsumen Texas Chicken Pekanbaru). Jurnal JOM FISIP.

Sangaji. (2017, Agustus 24). Liputan6. Retrieved from www.tekno.liputan6.com.

Sekaran, U., \& Bougie, R. (2010). Research Method for Business: A Skill-Building Approach. Haddington: John Wiley \& Sons.

Simamora, B. (2002). Panduan Riset Perilaku Konsumen. Jakarta: Gramedia Pustaka Utama.

Sinha, R. (2017, September 4). Buying a Smartphone: 10 Things to Consider. Retrieved October 20, 2017, from gadgetsnow.com.

Solecha, I. N. (2017, Agustus 15). HeroSoftMedia Digital Marketing Agency. Retrieved from www.herosoftmedia.co.id.

Vinod. (n.d.). 12 Things to Consider When Buying Electronic Items Online. Retrieved October 20, 2017, from listamaze.com.

Wang, C. C., Chen, C. A., \& Jiang, J. C. (2009). The Impact of Knowledge and Trust on E-Consumers' Online Shopping Activities: An Empirical Study. Taiwan: Journal of

Widiyanto, I., \& Prasilowati, S. L. (2015). Perilaku Pembelian Melalui Internet. Jurnal Manajemen dan Kewirausahaan, 109-122. 